WIDER Working Paper 2016/158

\title{
Industries without smokestacks
}

Mozambique country case study

Antonio S. Cruz ${ }^{1}$ and Fausto J. Mafambissa ${ }^{2}$

December 2016 
Abstract: Under the current international economic conditions, where Asian countries are strong competitors in the manufacturing commodities, low-income countries like Mozambique could attempt to compete in industries without smokestacks. Fruits and vegetables, agro-processing goods, and various tradable services are estimated to have contributed 1.9 per cent to annual average gross domestic product growth in 1993-2015, when the aggregate growth was 7.8 per cent. Around 80 per cent of the total labour force is dedicated to primary activities, producing 25 per cent of the aggregated value added in 2013-2015. The share of services in total exports was only 17 per cent in 2012-14. Although still relatively small, these industries have potential for growth, if Mozambique follows a diversified growth strategy.

Keywords: industries, exports, policy, growth strategy, national accounts, Mozambique JEL classification: L6, L8, O2, O4, O5

Acknowledgements: We are grateful to Finn Tarp, John Page, Richard Newfarmer, Claudio Frischtak, Ottavia Pesce, Joseph Laredo, and Fotini Antonopoulou for their comments and revision of this paper.

\footnotetext{
${ }^{1}$ Independent contractor, Sarajevo, Bosnia-Herzegovina, corresponding author: antonioscruz@gmail.com; ${ }^{2}$ Cabinet of the President, Maputo, Mozambique.

This study has been prepared within the UNU-WIDER project on 'Industries without smokestacks', which is part of a larger research project on 'Jobs, poverty and structural change in Africa'.
}

Copyright (C) UNU-WIDER 2016

Information and requests: publications@wider.unu.edu

ISSN 1798-7237 ISBN 978-92-9256-202-1

Typescript prepared by Joseph Laredo.

The United Nations University World Institute for Development Economics Research provides economic analysis and policy advice with the aim of promoting sustainable and equitable development. The Institute began operations in 1985 in Helsinki, Finland, as the first research and training centre of the United Nations University. Today it is a unique blend of think tank, research institute, and UN agency — providing a range of services from policy advice to governments as well as freely available original research.

The Institute is funded through income from an endowment fund with additional contributions to its work programme from Denmark, Finland, Sweden, and the United Kingdom.

Katajanokanlaituri 6 B, 00160 Helsinki, Finland

The views expressed in this paper are those of the author(s), and do not necessarily reflect the views of the Institute or the United Nations University, nor the programme/project donors. 
Considering the strong competition from Asian countries and other emergent economies in the export of manufacturing goods, Mozambique could attempt to break into the international market through exports from industries without smokestacks (IWSS ${ }^{1}$ ). This growth path could be an alternative, or even a complement, to a strategy of extracting and processing natural resources, while the country could also invest in smokestack industries.

Mozambique is a low-income Sub-Saharan African country that has been growing rapidly since 1993, at an annual average rate of 7.8 per cent, as a result of a series of transformations following its independence from Portugal in 1975, notably from a central planned economy to a market economy in the mid-1980s, from civil war to peace in 1992, and from a one-party system to a multi-party democracy in 1994-although, since 2012, there are signs that the last two transformations have been overturned: Mozambique is back to armed conflict ${ }^{2}$ between the state security and defence forces and Renamo armed forces, and the democracy seems to be more fragile in the 2010s than in previous years (AIM 2013, 2016a, 2016b; Kaiser and Rantala 2016).

The economy's rapid growth in the past two decades has been influenced by substantial inflows of foreign aid and foreign direct investment, a high rate of population growth and a young population, generally good weather conditions, significant investment in education, health, and basic public infrastructures, and legislative and institutional reform.

Nevertheless, Mozambique has not undergone a structural transformation like the industrialized countries and the emergent Asian and Latin-American economies. Around 80 per cent of Mozambique's labour force is still in agriculture, livestock, forestry, and fisheries, applying traditional manual and low-productivity technology (Tarp et al. 2002: 6-7; Chilonda et al. 2011: xv; Jones and Tarp 2012). It has a small and fragmented manufacturing sector producing for the internal market, and a large non-competitive and non-tradable services sector. The aluminium smelter is integrated into the international market but has a minor multiplier impact in the national economy, as it operates like an enclave. Extractive industries have been expanding, gradually from 2004 and more rapidly since 2011 — an expansion driven mainly by mineral coal exports.

With this type of structure, the economy is not improving its competitiveness in the international market; nor is it allowing small family producers in agriculture and fisheries and lower income producers in urban areas to increase their income significantly and sustainably. The poverty headcount ratio of the total population reduced slowly from 54.1 per cent in 2002-2003 to 49.2 per cent in 2014-2015, according to the official household budget survey analysis (MPD 2010; MEF 2016).

From 2010, economic policies increasingly targeted investment in natural resources exploitation, mainly mineral coal and natural gas. This policy choice resulted in a surge in foreign investment in

\footnotetext{
${ }^{1}$ Industries without smokestacks are activities producing horticultural products, fruits, and agro-industry goods, and providing tourism services, information-based services, and other tradable services (including transportation and communications).

${ }^{2}$ An International Peace Institute project on 'Understanding Compliance with Security Council Resolutions in Civil Wars' defined civil war as a conflict in which at least 500 battle deaths are reported during a given year, besides being a dispute concerning government and/or territory in a state, and involving two or more armed parties, one being the government of the state and the other a non-state opposition (Cockayne et al. 2010: 43).
} 
both products. However, the decline in international oil prices and the reduction in external demand for coal and natural gas in 2015, accompanied by a slowing of foreign investment, weak export performance, and a cut in foreign aid, led to a 135 per cent depreciation of the metical (MZN) against the US dollar between January 2015 and October 2016 and a rise in inflation from 1.9 per cent in December 2014 to 10.5 per cent in December 2015 and 25.5 per cent in October 2016 (INE 2015b, 2016a, 2016b; OANDA 2016). This unstable macroeconomic trend is likely to continue in the near future.

Also from 2010 onwards, the government tended to increase public investment by obtaining nonconcessional credit in the international market and consequently increasing external debt ratios (IMF 2010: 18, 2014a: 15; GdM 2016: 28). In the period 2012-2014, the Mozambican government allowed newly created companies led by high-ranking officials to obtain secret and non-secret loans with public guarantees from international banks amounting to US $\$ 2.3$ billion, most of them without parliamentary approval (Hanlon 2016; IMF 2016a; WSJ 2016). The resulting increase in external debt has aggravated the already unbalanced macroeconomic situation. Consequently, economic growth is slowing down and general living conditions are deteriorating, particularly for poor families.

This debt crisis may be partly due to the frailness of a strategy based on the extraction of natural resources mainly for export, and it prompts a search for alternative strategies that would enable the Mozambican economy to compete in the international market. The country will have to manage its limited resources much more carefully, and should look for other export opportunities based on the production of manufactured goods and services.

This paper uses hard data from statistics and other complementary sources to analyse the structural transformation of the economy as well as the size and the role of industries without smokestacks in the domestic economy (Section 2). It then presents the main public policies on macroeconomy, trade, labour, agriculture, and industry, and their impact on IWSS (Section 3) and outlines policy issues and challenges for the development of tourism as an IWSS case (Section 4). Section 5 presents conclusions.

\section{Development of industries without smokestacks, 1993-2015}

\subsection{Wide spectrum economy evolution vs. lack of structural transformation}

The transition to a market economy in the 1980s, the peace agreement with Renamo in 1992, the multi-party elections in 1994, and the transition from an apartheid regime to a multi-racial and multi-party system in South Africa in 1990-1994 formed the basic conditions for the recovery and growth of the Mozambican economy at an unprecedented pace and with a noticeable level of diversification (Figure 1).

In the 1980s and 1990s, macroeconomic stabilization and structural adjustment policies, including the World Bank's 'Heavily Indebted Poor Countries' initiative, created an enabling environment for price stability and economic equilibrium that was to a significant extent stimulated by external aid inflows (Tarp et al. 2002; IMF 2004: 4-5; USAID 2004: 1.1, 1.5). 'End of period' annual inflation reduced from 54.1 per cent in 1995 to 16.6 per cent in 1996, reaching an average of 2.9 per cent in 2011-2014 (IMF 2001: 4, 2014a: 18, 2015: 19). The difference between the official exchange rate of 2,742 MT/USD and the rate in the free market of 2,951 MT/USD in 1992 declined to 10,776 MT/USD and 10,890 MT/USD, respectively, in 1995 (IMF 2001: 100). 
Although this rapid (on annual average) growth pattern between 1993 and 2014 was diversified to some extent, it proved not to be sustainable, according to evidence in 2015-2016. The ratio of the current account deficit to GDP in nominal prices averaged 26.9 per cent in the period 1993-2015, but it showed an aggravation to 41.8 per cent in 2011-2015 (INE 2016d). Net international reserves declined from US $\$ 2,995$ billion at the end of 2013 to US $\$ 2,889$ billion at the end of 2015 , representing a decline from 3.3 months of imports of goods and non-factor services to 2.7 months (IMF 2016b). Around 80 per cent of the labour force is in the agriculture, livestock, forestry, and fisheries sectors (Jones and Tarp 2012). These primary sectors produced 34.1 per cent of the aggregated valued added in 1993-1995, but only 25.0 per cent in 2013-2015 (INE 2016c). The decline in the share of primary sectors in GDP was due mainly to an increase in the relative share of mining and services. Production in mining and services increased from 0.2 per cent and 51.2 per cent, respectively, to 4.6 per cent and 55.2 per cent in the same periods. Meanwhile, manufacturing, electricity, water, and construction experienced a slight change, from 14.5 per cent to 15.3 per cent. Mining occupies only 0.2 per cent of the labour force and services are mainly non-competitive in the international market or non-tradable. The share of services in total exports declined from an annual average of 35.5 per cent in 2000-2002 to 17.2 per cent in 2012-2014 (INE 1996-2015).

Figure 1: Transportation, hotels and restaurants, and information and communications together contributed 1.2 per cent to annual average growth in the period 1993-2015

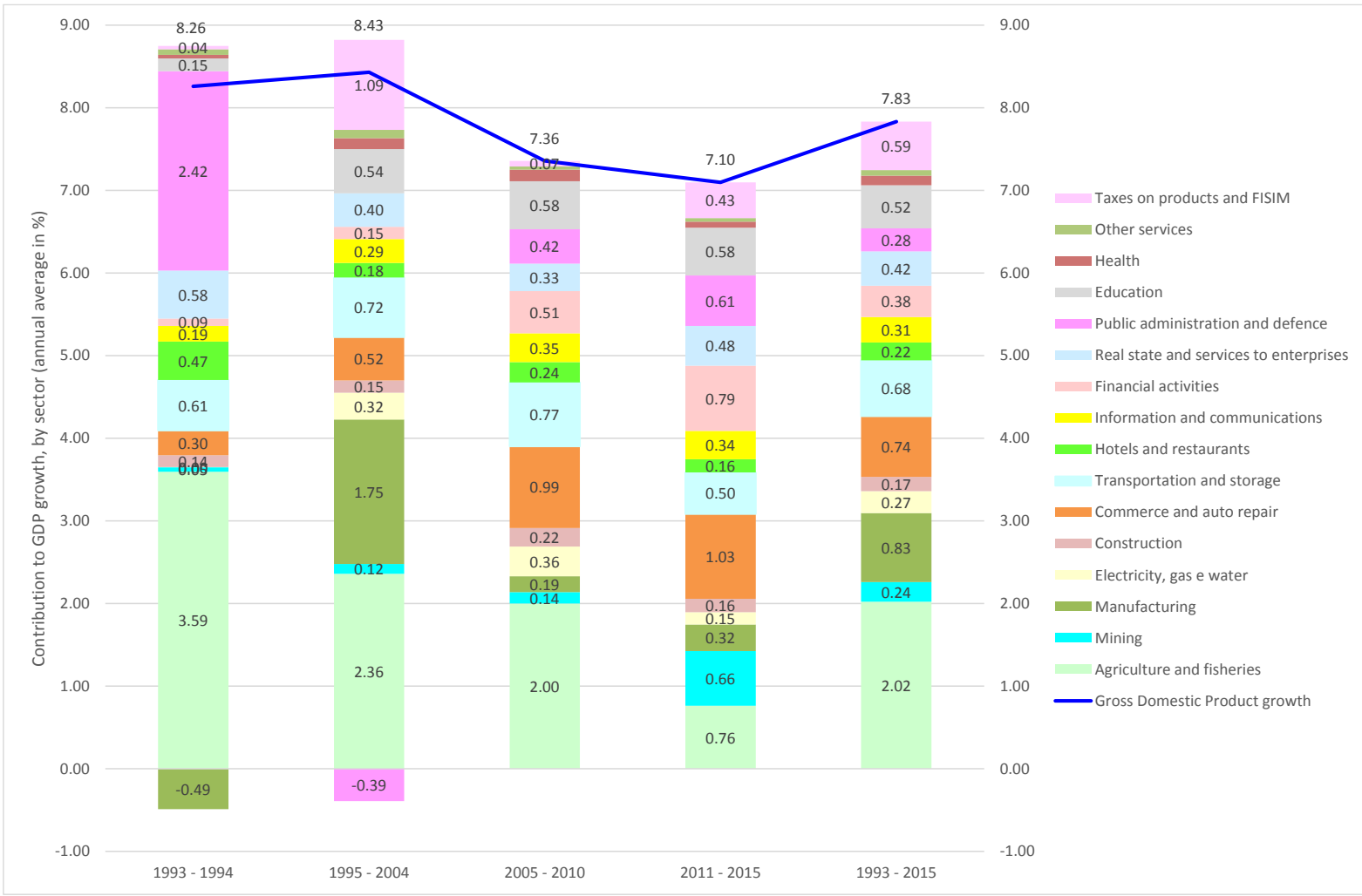

Source: Authors' calculations based on data from INE 2016c.

Evidently, the growth in the economy has been mainly directed at the internal market, but a large share of its labour force uses almost exclusively manual technology with low productivity rates (Tarp et al. 2002; Cruz et al. 2014). There is no evidence of a labour force transition from primary sectors to secondary and tertiary, accompanied by an increase in agricultural productivity, and no statistical evidence of a significant change in the economic structure in rural areas. The share of urban population in total population has been kept constant at around 30 per cent between the two most recent censuses of 1997 and 2007 (INE 1999b, 2010b). 
The annual average share of manufacturing in GDP increased from 13 per cent in 1993-1999 to 16 per cent in 2000-2007 (INE 2016c). The country's aluminium smelter started producing ingots in 2000, and contributed to an increase in the weight of manufacturing in GDP (Andersson 2002: 531, 540). But this share declined to 11 per cent in 2008-2015, as aluminium production stabilized while GDP continued to rise. Besides aluminium ingots, Mozambique exports manufactured goods. ${ }^{3}$ Annual average manufactured exports as a percentage of total exports of goods and services increased from 10.9 per cent in 2000-2007 to 20.6 per cent in 2008-2014 (INE 19962015; BM 2016). Including aluminium ingots, this share increases to 52 per cent in the whole period 2000-2014.

Although the share of manufacturing in total GDP is relatively small, its annual average value added per worker, at constant prices, of MZN151,000 places it fourth (below 'other services'including financial, information and communications, and real estate activities-at MZN214,000, mining at MZN235,000, and transportation and storage at MZN317,000) in the period 1993-2015 (Jones and Tarp 2012; INE 2016c). The 7.7 per cent annual average real growth rate of value added per worker in the manufacturing sector is the third highest in 1993-2015 after construction (10.3 per cent) and mining (21.4 per cent). Although this indicator dropped from an annual average of 13.9 per cent in 1993-2004 to 1.3 per cent in 2005-2015, the productivity per worker in manufacturing evidences the potential for value added creation and economic growth stimulation.

The role of services in the structural transformation of Mozambique has been mixed in 19932015. It is heavily weighted in the economy, with a 53 per cent annual average share of GDP, but it has a weak role in international transactions. While there is an increasing number of people in small commerce and other services at a subsistence level, there is also an increasing number of skilful young people working in transportation, information and communications, financial activities, and real estate. These skills require some degree of investment in education and the ability to operate with modern technology.

In terms of growth, the annual average contribution of services, excluding government, education, and health, increased from 2.4 per cent in 1993-2004 to 3.3 per cent in 2005-2015, whereas GDP growth was 8.4 per cent and 7.2 per cent, respectively. Services had an annual average of MZN114,000 of value added per worker, at constant prices. This places it in sixth position, below public administration and defence, with a value added per worker of MZN140,000. It is worth noting that the contribution of commerce activities is driving down the value added per worker in the overall services sector due to the large number of people dedicated to sales and to other services of subsistence remuneration. Even so, the annual average real growth rate of value added per worker in the services increased from 3.3 per cent in 1993-2004 to 6.4 per cent in 2005-2015, where the aggregated annual average real growth rate of value added per worker in 2005-2015 was 4.8 per cent.

When it comes to the international market, the annual average share of services in the total value of exports of goods and services was 21.5 per cent in 2000-2014. This share was just 18.5 per cent in 2008-2014. The large share of services in GDP does not match the much smaller share of services exports in total exports, or even the weak performance over time of services exports as a share of total exports.

\footnotetext{
${ }^{3}$ Manufactured exports include: food, beverages and tobacco; chemicals; plastics and rubber; leather; paper and cardboard; textiles; shoes; common metals; machinery and electrical equipment; transportation equipment; optical equipment, photographic equipment, and watches; medical equipment; and toys. Aluminium ingots are excluded from manufactured exports in this ratio.
} 
Although the economy has grown at a fast pace since 1993, with a certain degree of diversification, 80 per cent of its labour force live on income from agriculture and related activities using traditional manual and low-productive technology. The low share of manufacturing in total GDP, the structure and dynamics of exports based on primary commodities or selected commodities/ services from large projects with weak linkages to the internal economy, and the large services sector as a proportion of GDP with little competitiveness in the international market are signs of a lack of structural transformation.

\subsection{Industries without smokestacks}

This section accounts for the performance of IWSS - with a caveat on the level of precision, as the data available vary in terms of disaggregation ${ }^{4}$ degree (Table 1). Besides IWSS, other Mozambican non-traditional products with potential for export growth are maize, sesame, and soybeans, but these will not be dealt with in detail in this paper.

Table 1: Estimated contribution of IWSS to GDP growth in 1993-2015 (\%)

\begin{tabular}{lll}
\hline & Industries without smokestacks & Rest of the economy \\
Contribution to GDP growth & 1.9 & 5.9 \\
\hline
\end{tabular}

Note: The composition of IWSS in the GDP comprises the following sectors: agricultural and fisheries (16.98\%), manufacturing $(45 \%)$, transportation and storage, hotels and restaurants, and information and communications.

Source: Authors' calculations based on data from INE 2016c and on Fig. 1.

In the agriculture sector, production of citrus fruits increased at an annual average of 6.7 per cent in 1993-2014, and the volume of tomatoes and horticultural products increased at an annual average of 8.0 per cent and 12.6 per cent, respectively, in 1993-2002. No production statistics for tomatoes and horticultural products are available from 2003 onwards in the official Statistical Yearbook series. Nevertheless, the annual average exports of horticultural products increased from US\$282,000 in 1996-1998 to US\$15.4 million in 2006-2009 (MPF-DNE 1994-1995; INE 19962015). This indicator also increased slightly for fruit exports, from US\$34.4 million in 1995-1998 to US $\$ 36.3$ million in 2006-2009. In particular, banana exports increased significantly in 2011 due to a foreign direct investment project in Nampula Province. ${ }^{5}$

Manufacturing output increased its share of GDP to 18 per cent in 2001, but this subsequently declined to an annual average of 10 per cent in 2012-2015. Gross value added (GVA), in current prices, of food processing, textiles and garments, and wood processing represented 32 per cent, 5 per cent, and 9 per cent, respectively, of aggregate GVA in manufacturing in 2010-2015 (INE 2016e). GVA of these three manufacturing sub-sectors represented 4.5 per cent of aggregated GVA in the economy. The annual average GVA variation in current prices of food processing, textiles and garments, and wood processing was 9.9 per cent, 6.2 per cent, and 7.7 per cent, respectively, in 2010-2015. The variation in the same indicator for the manufacturing sector was 8.5 per cent, and for the entire economy 11.2 per cent.

Agro-processing-of sugar, cashew nuts, and cotton fibre-for export has been a traditional activity in Mozambique since before independence, and continues today (Dias 2012; Sutton 2014). Maize flour, refined edible oil, and processed tea are also exported at a more modest revenue.

\footnotetext{
${ }^{4}$ It should be noted that 'industries without smokestacks' does not have a specific classification in national accounts; nor it is treated as a specific GDP component in the official statistics in Mozambique. Therefore, any attempt to aggregate IWSS activities runs the risk of either over-estimation or under-estimation of this set of goods and services in total GDP.

${ }^{5}$ Banana exports reached an annual average of US\$70.9 million in 2011-2014 (BM 2016).
} 
Processed wood is also currently exported. Processed rice is traditionally consumed in the domestic market, and soybean production is expanding for poultry feed (Calima et al. 2014). There are plans to attract foreign direct investment on two paper pulp projects, in Zambézia and Nampula provinces, amounting to US $\$ 4.5$ billion (MPD and MF 2012: 12).

Transportation and storage accounted for 10.1 per cent of GVA in the aggregated economy in 1993-2015, and has been growing at an annual average of 7.8 per cent, which is the same rate as GDP. With an annual average of 47 billion passenger-kilometres, road transportation accounted for 98 per cent of the total passenger traffic transported by rail, sea, air, and road in 2009-2015 (MTC 2016). Railway (40 per cent) and road (51.5 per cent) transportation account for an annual average of 2.8 and 3.6 billion ton-kilometres transported in 2009-2015, respectively. Railway transportation grew by 387 per cent between 2009 and 2015 due to the extraction of mineral coal, mainly after 2011. Total cargo handling in the country's main ports increased from 12.7 million tonnes in 2009 to 32.1 million tonnes in 2015 (MTC 2016).

GVA in tourism (hotels and restaurants) accounted for 2.2 per cent of aggregated value added in 1993-2015. This sector has been growing at an annual average rate of 9.1 per cent, which is higher than GDP growth. This is a sector with potential for growth, in both the domestic and the international markets. One factor that could increase the flow of tourists from abroad is a more cost-efficient air transportation service. International demand and safety inside Mozambique are other relevant factors influencing tourism (Batey 2014).

Regarding the GDP production approach, national accounts statistics do not provide disaggregated data on 'information-based services', but on the aggregated information and communications sector. The share of these services in total GDP was 3.3 per cent in 1993-2015. This sector contributes 0.31 per cent to GDP growth, well above the sectors hotels and restaurants ( 0.22 per cent), electricity, gas, and water ( 0.27 per cent), and public administration and defence (0.28 per cent) (Figure 1). The share of gross value added for consultancy, scientific, and technical services in total GVA is 2.1 per cent, based on nominal values for 2010-2015 (INE 2016e). The total number of mobile phone subscriptions increased from 5.9 million in 2009 to 20.1 million in 2015 (MTC 2016). In terms of exports as a share of total exports of services, technical assistance and services related to commerce (14 per cent) and telecommunications, computers, and information services ( 5 per cent) were ranked third and fourth, respectively, after transportation (43 per cent) and travel (31 per cent) in 2006-2015 (BM 2016). The low share of information and communication technology in total exports allows us to hypothesize that Mozambique is mainly importing information-based technology in order to increase productivity across sectors producing for the domestic market.

From the limited information available, there is evidence that IWSS have been contributing to economic growth in Mozambique since 1993, but there is no evidence of a significant contribution to the expansion of its goods and services in the international market.

\section{$3 \quad$ Selected public policies}

This section reviews macroeconomic, trade, labour, agricultural, and industrial policies that have influenced economic performance since 1993, in particular in relation to IWSS. A recent and detailed policy review is presented in UNU-WIDER Working Paper 2014/059 (Cruz et al. 2014). 


\subsection{Macroeconomic policies}

The Mozambican government implemented the Economic Rehabilitation Program (PRE) from 1987 onwards, although initial price reforms started earlier in the same decade (USAID 2004). This macroeconomic stabilization and structural adjustment programme represented a transition from a centrally planned economy to a market economy system, and it was designed to reverse the declining trend of the economy in a civil war context.

In the period from 1980 to 1984, the economy declined by 26 per cent (Sulemane 2002). Exports and imports fell, while the trade deficit aggravated from US\$-320 million in 1979 to US\$-444 million in 1984, reaching US\$-607 million in 1982. Foreign debt-service obligations amounted to more than twice the value of exports of goods and services in 1985 (IMF 2004: 5). Thus, foreign currency was in short supply, which drove the parallel (black) market exchange rate downwards and increased the gap with the official exchange rate (Hanlon 1991; Tarp et al. 2002: 25-26). The government was able to cover its deficit by printing money, adding pressure for an increase in prices in the parallel market, i.e. driving up inflation (Tarp 1990).

In order to reverse this trend, the government progressively devalued the official exchange rate and gradually liberalized prices, interest rates, and trade (IMF 1996, 2004). It also restricted public expenditure and the money supply, and reformed the system of revenue collection. Although basic policies were implemented in the first years of the PRE, it was only after the peace agreement in 1992 that economic growth accelerated from an annual average of -6.6 per cent in 1990-1992 to 6.9 per cent in 1993-1995, and end-of-the-period inflation declined from 54.1 per cent in 1995 to 16.6 per cent in 1996 and 5.8 per cent in 1997 (IMF 2001; Sulemane 2002).

Fiscal reforms, privatization programmes, and financial sector reforms continued after 1992, with the aim of reducing macroeconomic imbalances and improving efficiency and competition in the economy. As a result of successful policies and reforms, Mozambique benefited from debt relief from donors under the Highly Indebted Poor Countries initiative from 1998 to 2002 amounting to US $\$ 2.7$ billion in 1999 values (IMF 1998: 3, 1999).

The country continued to implement market-oriented macroeconomic policies and structural reforms until 2015 (IMF 2014b: 1, 2016b). Taxation reforms-in particular, institutional reforms such as the creation of the Tax Authority-led to an increase in the state revenues to GDP ratio from 12.4 per cent in 2004 to 25.5 per cent in 2015 (Barnes et al. 2016; IMF 2016b). This improved macroeconomic performance allowed economic agents to take resource allocation decisions partly on the basis of price signals.

However, many distortions and weaknesses remain, such that the Mozambican economy has not yet reached the point of Pareto efficiency. To a large extent, the public deficit has been financed by external aid and public borrowing, with transparency and accountability shortfalls, in particular between 2012 and 2015 (GdM 2016; IMF 2016a; WSJ 2016). Furthermore, the exchange rate dynamic has not always been favourable to the tradable sectors, in particular agriculture.

\subsection{Trade policies}

The exchange rate was devalued in 1987 and in the following years of the PRE. Subsequently, the exchange rate tended to be determined by the market. The tariff book was simplified in 1996 (USAID 2004). In 2004, the Most Favoured Nation duty structure included ad valorem percentage rates of 0, 2.5, 5, 7.5, and 25 (Alfieri et al. 2006: 6-7). In 2006, the highest rate dropped to 20 per cent. Following the SADC Trade Protocol, Mozambique had gradually liberalized trade with most member countries by the end of 2012, and with South Africa by the end of 2015 (PdM 2009). 
Mozambique is a member of the World Trade Organization and has preferential market access with the European Union under the Everything but Arms and the Economic Partnership Agreements, and with the Unites States under the African Growth and Opportunity Act (USAID 2004: 5-1, 5-2).

In the 1990s, an interbank foreign exchange market was developed and customs exemptions were reduced (IMF 2004: 6, 7). Customs procedures were reformed (IMF 2004: 12). In 2006 the creation of the Tax Authority was an institutional reform milestone. These reforms were aimed at reducing the costs of international trade and increasing control over tax revenues. Complementary reforms were introduced to promote an enabling business environment and trade, such as the creation of the one-stop shop and the abolition of visas for many SADC countries (Imani Development International 2007: 3). Mozambique has also developed legislation and started implementing Export Promotion Zones at a moderate pace, mainly in Beluluane and Nacala.

As a result of trade liberalization and reforms, as well as foreign direct investment in mineral resources such as heavy sands, natural gas, and coal, and other investments (in the hydroelectric power system, sugar, and tobacco), exports grew at an annual average rate of 14.9 per cent between 1993 and 2015 (INE 2016d). Imports grew at 11.5 per cent in the same period. The current account deficit as a percentage of nominal GDP reduced from -43.7 per cent in 1995 to -9.1 per cent in 2007, reflecting an upward trend in exports. This ratio aggravated to -53.6 per cent in 2013, however, due to large foreign direct investment in the exploitation of coal in Tete province and natural gas in the Rovuma basin. The current account deficit declined in the period up to 2015 as imports reduced at a faster rate than exports due to the reduction in international prices of coal and natural gas, and the postponing of investment in the latter commodity.

Some analysts have been arguing in favour of Mozambique advancing further with trade liberalization, by continuing to reduce tariffs, applying a flat rate, complying with WTO rules, facilitating visas and international work permits, and reducing transportation and port costs (Flatters 2002; USAID 2004; Menon 2014). Such measures would reduce transaction costs and increase the competitiveness of Mozambican exports. Other analysts consider that trade liberalization has limitations as a promoter of exports insofar as (i) such a policy fails to protect producers for the external market from a deterioration in international terms of trade, (ii) the market power of private companies prevents local producers from competing on the international market, and (iii) foreign aid will contribute to an overvalued local currency, reducing competitiveness in the external market (Castel Branco 1997; Mosca et al. 2014).

\subsection{Labour policies}

Labour policies in Mozambique are managed by the Ministry of Labour, Employment and Social Security (MITESS). This institution is responsible for devising and monitoring government policies, for coordinating the National Social Security System, and for participating in national minimum-wage negotiations. Two major trade union confederations, the Mozambique Workers' Organization (OTM) and the Mozambique Independent and Free Union Confederation (CONSILMO), participate in the annual minimum-wage definition together with the Confederation of Business Associations of Mozambique (CTA) and the Mozambican government. MITESS is also responsible for the management of the foreign-worker quota system and oversees vocational education and training through the National Institute of Employment and Vocational Training (INEFP).

Over time, several instruments have been used in order to implement labour policies. As part of public sector reform, a significant improvement in the business environment was achieved through 
the simplification of administrative procedures, and the last revision of the labour law came into force in 2007, when Law 23/2007 replaced Law 8/1998 (PdM 2007).

Law 23/2007 included new provisions for the promotion of entrepreneurship and the protection of workers, most notably strengthening job security, preventing unfair dismissal, protecting the dignity of workers, and extending their rights to trade union activity, to strike, to social security, to fair remuneration, to rest periods, to holidays, to maternity and paternity leave, to retirement schemes, and to pre-professional training. The new labour law also created an extra-judicial system for the resolution of labour disputes. The recently approved Employment Policy aims at harmonizing and aligning various strategic actions to induce improvements to the business environment and to the labour market (MITESS 2016).

The latest report on the manufacturing enterprises survey in Mozambique in 2012 shows that there is a slight improvement in labour legislation, which is thus becoming less of a constraint in the labour regulations environment than it appeared in the 2006 survey (Rand and Tarp 2013).

\subsection{Agricultural and industrial policies}

Agricultural policies in Mozambique have elicited a positive response from smallholder agricultural producers to price incentives, improvements to road and ports infrastructure, and improvements in basic trading services. The same incentives have elicited a positive response from commodity producers for the external market (e.g. sugar and tobacco). According to official agricultural production figures, aggregate agricultural production increased by an annual average rate of 6.7 per cent between 1993 and 2015 (INE 2016c), although these figures are considered to be overestimated (Pauw et al. 2012: 2). Nevertheless, agricultural production is still based on a large number of family smallholder units using traditional and manual technology, and low levels of technical input. Hence, agricultural productivity remains low (Cunguara et al. 2012: 121; Pauw et al. 2012: 8-9; Benfica et al. 2014: 17).

Industrial policies from 1992 onwards were 'hands-off, with the government undertaking limited initiatives. Markets were meant to determine where investors should allocate their resources. A broad privatization programme was implemented that eliminated bankrupt companies, reduced public expenditure on inefficient companies, and permitted private reinvestment in a small proportion of running enterprises. The impact of the privatization programme on industrialization in Mozambique is considered to be far from successful in terms of manufacturing diversification and expansion, or in terms of employment generation (Castel-Branco et al. 2001: 11-12; Dibben and Wood 2016). Privatization also requires careful preparation and analysis in order to address the country-specific conditions (Torp and Rekve 1998). Such a privatization process would permit supportive measures like access to credit and encourage national entrepreneurs, which has not always happened in Mozambique.

On the other hand, the Export Promotion Zones policy led to one major capital-intensive foreign direct investment project, the aluminium smelter. However, this mega-project is considered an enclave, with weak connections to the rest of the domestic economy. Other, smaller-scale, successful industries produce a variety of goods, though mostly food and beverages, for the domestic market, and tobacco and sugar, mainly for the international market. In general, though, industrial policies have failed to promote manufacturing diversification and expansion of output as a proportion of GDP, in particular since 2004 (Cruz et al. 2014). The state strongly influences the creation and development of enterprises through the licensing process, labour inspections, and tax inspections. 
The Industrial Policy and Strategy approved by the government in 2016 defined its main objective as transforming manufacturing into the main vehicle for the country to achieve prosperity and improve living conditions, through generating employment, increasing production, and processing natural resources. A local content law is currently being drafted in order to address the need to develop further connections between local companies and extractive industries.

Given the young population structure of the country and the high unemployment rate, especially in urban areas, labour-intensive manufacturing production could play a role in the growth of jobs, income expansion, and industrial intensification. Yet this kind of production, in particular for exports, has not been developed in Mozambique due to poorly designed, coordinated, and implemented industrial and competitiveness policies (Krause and Kaufmann 2011: 54; Rand et al. 2014: 15). The newly approved Industrial Policy and Strategy could change this pattern if the government avoids falling into the high-value natural resources sector trap and being driven by foreign investment decisions.

\subsection{IWSS policies}

Production of horticultural products and fruits for export has benefited from the general investment promotion legislation. This was the case with citrus production in Boane; baby corn, fresh chilies, green beans, mange tout peas, sugar snap peas, and okra production in Vanduzi; and banana production in Nampula. However, there has not been a significant increase in horticultural and fruit production for export. Encouraging large foreign investment projects has not been and will not be the only way of increasing exports of these commodities. Due to the very large number of smallholder agricultural producers ( 4.2 million), it will be necessary to encourage them to participate in export projects as producer units and not only as a source of cheap labour (MASA n.d.).

Regarding agro-processing for export, previous and current industrial policies have been and still are ineffective. It requires political will and stronger local business interests to remove the business barriers that are well known and highlighted in the World Bank's 'Doing Business' annual reports. It would also require a persistent and continuous effort in terms of public policies directed at promoting agro-processing projects to allow the expansion of this sub-sector (MPD 2014). Poverty reduction strategy papers since 2001 have weakened the industrial policy component in the set of public policies. At least 70 per cent of the state budget has been allocated to 'social sectors and other priority sectors related to poverty alleviation', at the expense of the industrial sector (GdM 2001). At the same time, natural resources extraction for export has gradually become the economic policy focus due to the perception that it could provide the required revenue to finance the expanding state budget and the opportunity for national interest groups to profit from allowing international extraction of mineral coal, natural gas, and other minerals (e.g. heavy sands and precious stones).

Transportation, communications, and information policies have promoted the rehabilitation and construction of roads and railways connecting landlocked countries/regions with the Indian Ocean and opened the market for passenger and cargo road transportation companies and for mobile telephone and internet provider services. Nevertheless, further competition in these areas could contribute to an improvement in the quality of services and a reduction in costs for the consumer. Since the late 2000s, Mozambique has been open to various international air transport companies. Currently, seven international airlines fly to Maputo or other cities in the country. The challenges for the Mozambican government are the increase in competition in the domestic flight market, and the reduction in the fares charged by the Mozambican national airline, LAM, which needs to improve the quality and reliability of its services in order to achieve international standards. Tourism policy issues are discussed in the next section. 
While economic growth is largely being fuelled by investment in the exploitation of mineral resources (coal and hydrocarbons) and related infrastructure, the tourism sector is seen as an opportunity to diversify the economy through its potential for export expansion, job creation, skills learning, and income generation. Tourism development requires investment in basic infrastructure (road networks, water and sanitation, energy, and health centres), as well as in the provision of excellent services in terms of technology and transportation, which are sought by increasingly demanding customers (Jones 2007; Jones et al. 2007; Portuguez et al. 2012).

Mozambique can be considered an attractive destination for tourism because of its natural conditions, biodiversity, and cultural diversity. Its coastline of over $2,700 \mathrm{~km}$ offers excellent beaches, bays, and lagoons. About 15 per cent of the country is classified as a protected area (IFC 2012). Below is a brief profile of each of the country's three regions (MITUR 2004: 62):

- The North region includes the provinces of Cabo Delgado, Nampula, Niassa, and Zambézia. The tourism targets are centred on its coastal potential (beaches, islands) and on eco-tourism, based on the wild natural characteristics of the region, with distinctive cultural influences. The North has protected areas, such as the National Park, Quirimbas Archipelago, Island of Mozambique, Niassa Reserve, and Lake Niassa. Eco-tourism activities like bird-watching and lake activities will be developed in remote areas of Niassa and Cabo Delgado.

- The Centre region includes the provinces of Sofala, Manica, and Tete. Tourism initiatives are based on the development of eco-tourism and beach and sun holidays. It also has protected areas, including the Gorongosa National Park (ideal for eco-tourism and safari holidays) and Cahora Bassa.

- The South region comprises the provinces of Maputo, Maputo City, Gaza, and Inhambane. The possibilities include beach and watersports holidays, diving, ocean safaris, ecotourism, and cultural activities. Its reserve areas include the Limpopo Transfrontier Conservation Area (eco-tourism), Maputo-Province Special Reserve (eco-tourism), Inhaca and Bazaruto (sun, sand, and sea), Inhambane (culture and diving), and Maputo City (culture and entertainment).

In order to take advantage of the country's tourism potential, the government has also approved a tourism law (GdM 2004).

\subsection{Opportunities and challenges}

Tourism services are growing faster than the rest of the economy. However, these services are still far from achieving their potential, and the sector has opportunities that could be further explored, such as combining sun and beach resorts with eco-tourism, cruises, events, business, or gambling.

According to the Second Strategic Plan for the Development of Tourism 2015-2024 (PEDT II), tourism development is facing four main category barriers, which need to be addressed: (i) access, (ii) demand, (iii) investment, and (iv) institutional capacity (Fernando 2013; MITUR 2015a). 
- Access - The high cost of air transportation prevents the country from competing in the region and internationally in the tourism market. Even road access to many tourist areas is difficult.

- Demand - Demand is negatively affected by corruption, the hostile attitude of police towards tourists, poaching, the unstable military and political situation, and negative publicity disseminated by the mass media. Mozambique's wildlife tourism experience is limited in comparison with other countries in the region, a problem exacerbated by a decrease in wildlife numbers and inadequate provision of activities and services.

- Investment - There is significant regional competition in tourism services, and delays in the processing of access to land and permission for its exploitation are considered bottlenecks. There is a limited supply of goods and services to tourist companies from other sectors within the domestic economy, against a significant level of imports, and the sector suffers from modest levels and low quality of equipment. Taxes on tourism activities are considered high, and loans to tourism companies are limited.

- Institutional capacity - The quality of tourism training institutions and available skills are limited. Public sector services and public-private partnerships at the national, provincial, and local levels are inadequate in terms of the implementation of tourism plans.

Recently, however, the Government of Mozambique has adopted a new approach to the development of tourism, which focuses on an integrated plan identifying Touristic Interest Areas and Investment Priority Areas in the provinces of Inhambane, Zambézia, Nampula, Cabo Delgado, and Niassa (MITUR 2013, 2015b).

\section{Conclusion}

Under the current international economic conditions, where Asian countries are strong competitors in the manufacturing commodities, low-income countries like Mozambique could attempt to compete in industries without smokestacks. Examples of commodities and activities in which Mozambique could compete on the international market are baby corn, green beans, citrus fruits, bananas, mangos, cut flowers, maize and related products, sesame, tourism, electricity from hydropower plants and natural gas plants, and transportation services.

An analysis of the last two decades, during which Mozambique has followed an upward economic growth path, reveal that the country has not undergone a structural transformation like those of the industrialized countries and the emergent Asian and Latin-American economies-i.e. an expansion of the manufacturing sector, as a share of GDP and a share of the total labour force, and an increase in agricultural productivity accompanied by a reduction in its share of the labour force due to the migration to other more productive sectors in the economy. In Mozambique, about 80 per cent of the labour force is in agriculture and other rural activities, producing about 25 per cent of GDP. Manufacturing output as a share of GDP has been declining since 2001, to 10 per cent in 2015. The economy is mainly growing inwards with limited expansion of exports, in particular of labour-intensive goods and services.

The government's growth strategy since 2010 has been focused on international investment in mineral coal and natural gas, as well as on expansion in public infrastructure investment, with a growing share of external commercial lending. The country's economic performance in 2015 and 2016 reveals that this strategy is risky and unsustainable. Lower international demand for 
commodities in general, and coal and natural gas in particular, a sharp rise in external public debt, a decline in foreign aid, and public policy mismanagement are causing a serious economic crisis.

Mozambique is in dire need of reversing its macroeconomic and other policies in order to stabilize the economy. Meanwhile, a diversified growth strategy could promote synergies to expand output from agriculture and related activities, and other industries without smokestacks, so that these sectors can compete on the international market. An open and transparent public policy on the exploitation of coal, natural gas, and other high-value natural resources could integrate these products into a processing value chain, such that the country's economy could gradually industrialize. For any economic policy to obtain meaningful results, the restoration of peace in the country is a pre-condition.

\section{References}

AIM (Agência de Informação de Moçambique) (2013). 'Governo e Renamo novamente em negociações'. Noticias, 18 April. Available at: http://noticias.sapo.mz/aim/artigo/752118042013180849.html (accessed 12 December 2016).

AIM (2016a). 'Retomado diálogo político e prossegue terça-feira'. Noticias, 8 August. Available at: http://www.portaldogoverno.gov.mz/por/Imprensa/Noticias/Retomado-dialogo-politicoe-prossegue-terca-feira (accessed 12 December 2016).

AIM (2016b). 'Negociações serão suspensas por mais de uma semana'. Noticias, 25 October. Available at: http://macua.blogs.com/moambique_para_todos/2016/10/negocia\%C3\%A7\%C3\%B5esser\%C3\%A3o-suspensas-por-mais-de-uma-semana.html (accessed 12 December 2016).

Alfieri, A., X. Cirera, and A. Rawlinson (2006). 'Estimating the Impact on Mozambique of Different Trade Policy Regimes: SADC, SACU or MFN?'. DNEAP Discussion Paper 29E, August. Maputo: Ministry of Planning and Development.

Andersson, P.-Å. (2002). 'Impacto dos megaprojectos na economia Moçambicana'. In A Economia Moçambicana Contemporanea: Ensaios. Maputo: Gabinete de Estudos, Ministério do Plano e Finanças.

Barnes, H., V. Castelo, F. Castigo, A. Cruz, M. Mpike, M. Noble, and G. Wright (2016). 'Taxbenefit Microsimulation Modelling in Mozambique'. WIDER Working Paper 2016/27. Helsinki: UNU-WIDER.

Batey, E. (2014). 'Custo económico do conflito em Moçambique: avaliação do impacto económico do conflitos no sector do turismo'. Maputo: SPEED. Available at: http://www.speedprogram.com/wp-content/uploads/2014/05/2014-SPEED-Report-005-Economic-cost-ofrenewed-conflict-in-Mozambique-Tourism-value-chains-PT.pdf (accessed 22 February 2016).

Benfica, R., D. Boughton, B. Mouzinho, and R. Uaiene (2014). 'Food Crop Marketing and Agricultural Productivity in a High Price Environment: Evidence and Implications for Mozambique'. Directorate of Economics: Research Paper 76E, May. Maputo: Ministry of Agriculture.

BM (Banco de Moçambique) (2016). 'Balança de Pagamentos' for years 2006-2015. File $<15 \_40 \_l n k \_p t \_B a l a n c a . x l s x>$, downloaded from website www.bancomoc.mz on 28 April 2016. 
Calima, J., M.N. Dengo, C. Moamba, and L. Salinger (2014). 'Mozambique's Natural Resource Boom: What Potential Impacts on Agriculture's Competitiveness?' SPEED/Reports/2014/010. Prepared for USAID's SPEED Program. Maputo: DAI and Nathan Associates, October.

Castel Branco, N. (1997). 'The Limits of Trade Liberalization for Export Promotion in SubSaharan Africa'. Master of Sciences Dissertation. Oxford University.

Castel-Branco, N.C., C. Cramer, and D. Hailu (2001). 'Privatization and Economic Strategy in Mozambique'. WIDER Discussion Paper 64. Helsinki: UNU-WIDER.

Chilonda, P., et al. (2011). 'Monitoring Agriculture Sector Performance, Growth and Poverty Trends in Mozambique'. 2010 Annual Trends and Outlook Report. Maputo: Mozambique Strategic Analysis and Knowledge Support System, in collaboration with MINAG, ICRISAT, IFPRI and IWMI. Available at: http://www.resakss.org/sites/default/files/pdfs/MozSAKSS_ATOR_2010.pdf (accessed 24 June 2016).

Cockayne, J., C. Mikulaschek, and C. Perry (2010). 'The United Nations Security Council and Civil War: First Insights from a New Dataset'. New York: International Peace Institute. Available at:

https://www.ipinst.org/wpcontent/uploads/publications/ipi_rpt_unsc_and_civil_war_epub.pdf_ (accessed 12 December 2016).

Cruz, A.S., D. Guambe, C. Marrengula, and A.F. Ubisse (2014). 'Mozambique’s Industrialization'. WIDER Working Paper 2014/059. Helsinki: UNU-WIDER.

Cunguara, B., G. Fagilde, J. Garret, R. Uaiene, and D. Heady (2012). 'Growth Without Change? A Case Study of Economic Transformation in Mozambique'. Journal of African Development, 14(2): 105-30.

Dias, P. (2012). 'Analysis of Incentives and Disincentives for Cotton in Mozambique'. Technical Notes Series, MAFAP. Rome: FAO.

Dibben, P., and G. Wood (2016) 'The Legacies of Coercion and the Challenges of Contingency: Mozambican Unions in Difficult Times'. Labour History, 57(1): 126-40, DOI: 10.1080/0023656X.2016.1140707.

Available at: http:/ / repository.essex.ac.uk/16908/1/The\%20legacies\%20of\%20coercion\%20and\%20the $\% 20$ challenges $\% 20$ of $\% 20$ contingency $\% 20$ Mozambican $\% 20$ unions $\% 20$ in $\% 2$ difficult $\% 20$ ti mes.pdf (accessed 31 August 2016).

Fernando, M. (2013). 'Politicas de Turismo e a sustenbilidade socio-ambiental em Moçambique: a experiencia das “Áreas Prioritárias para o Investimento Turístico - APIT’s” e seus impactos no Município'. Available at: http://tede.biblioteca.ufpb.br/bitstream/tede/4543/1/arquivototal.pdf (accessed 2 February 2016).

Flatters, F. (2002). 'Trade Policy Strategy for Mozambique'. Prepared for USAID - Mozambique. Queen's University, Canada, December.

GdM (Governo de Moçambique) (2001). 'Plano de Acção para a Redução da Pobreza Absoluta 2001-2005'. Maputo, April.

GdM (2004). 'Lei do turismo'. Available at: http://www.portaldogoverno.gov.mz/Legisla/legisSectores/turismo_leg/lei\%20do\%20turi smo.pdf (accessed 22 February 2015). 
GdM (2016). 'Discurso do Primeiro-Ministro sobre a dívida pública', 28 April. Available at: http://www.folhademaputo.co.mz/pt/noticias/nacional/discurso-do-primeiro-ministrosobre-a-divida-publica-na-integra/ (accessed 30 June 2016).

Hanlon, J. (1991). 'Mozambique: Who Calls the Shots?'. London: James Curry; Bloomington and Indianapolis: Indiana University Press.

Hanlon, J. (2016). 'Mozambique Banks Hold Proindicus, Ematum Debt'. In Mozambique News reports \& clippings 330, 11 July. Available at: http://www.open.ac.uk/technology/mozambique/news-reports-clippings (accessed 11 July 2016).

IFC (International Finance Corporation) (2012). 'Facilitating Large Scale Tourism Resorts in Mozambique: The Tourism Investment Generation Approach'. Washington, DC: The World Bank - Investment Climate Advisory Services. Available at: http://www.ifc.org/wps/wcm/connect/4b9953804b7f31598974cbbbd578891b/CoastalRe sortsStudy.pdf?MOD=AJPERES (accessed 15 November 2016).

Imani Development International (2007). '2007 Update Survey of Non-tariff Barriers to Trade: Mozambique'. Prepared for Regional Trade Facilitation Programme in association with Austral Consultoria e Projectos Lda, July.

IMF (International Monetary Fund) (1996). 'IMF Approves Three-year Loan for Mozambique Under the ESAF'. Press Release 96/33. Washington, DC: International Monetary Fund. Available at: https://www.imf.org/external/np/sec/pr/1996/pr9633.htm (accessed 1 June 2016).

IMF (1998). 'Enhanced Structural Adjustment Facility: Policy Framework Paper for 1998-2000'. Washington, DC: International Monetary Fund. Available at: http:/ / www.imf.org/external/np/pfp/mozam/moz.htm (accessed 1 June 2016).

IMF (1999). 'Mozambique to Receive US\$3.7 Billion in Debt Relief Through the HIPC Initiative'. News Brief 99/35, 30 June. Washington, DC: International Monetary Fund. Available at: http://www.imf.org/external/np/sec/nb/1999/nb9935.htm (accessed 1 June 2016).

IMF (2001). 'Republic of Mozambique: Selected Issues and Statistical Appendix'. IMF Country Report 01/25. Washington, DC: International Monetary Fund. Available at: https://www.imf.org/external/pubs/ft/scr/2001/cr0125.pdf (accessed 1 June 2016).

IMF (2004). 'Republic of Mozambique: Ex Post Assessment of Mozambique's Performance Under Fund-Supported Programs'. IMF Country Report 04/53. Washington, DC: International Monetary Fund. Available at: https://www.imf.org/external/pubs/ft/scr/2004/cr0453.pdf (accessed 1 June 2016).

IMF (2010). 'Mozambique: First Review Under the Policy Support Instrument and Request for Modification of Assessment Criteria-Staff Report; and Press Release'. IMF Country Report 10/375. Washington, DC: International Monetary Fund. Available at: http://www.imf.org/external/pubs/ft/scr/2010/cr10375.pdf (accessed 2 June 2016).

IMF (2014a). 'Second Review under the Policy Support Instrument and Request for Modification of Assessment Criteria; Staff Report; Debt Sustainability Analysis; Press Release; and Statement by the Executive Director for Republic of Mozambique'. IMF Country Report 14/148. Washington, DC: International Monetary Fund. Available at: https://www.imf.org/external/pubs/ft/scr/2014/cr14148.pdf (accessed 2 June 2016).

IMF (2014b). ‘Mozambique Rising: Building a New Tomorrow'. Doris C. Ross (ed.). Washington, DC: International Monetary Fund, African Department. Available at: http://www.imf.org/external/pubs/ft/dp/2014/afr1404.pdf (accessed 2 June 2016). 
IMF (2015). 'Republic of Mozambique: Fourth Review under the Policy Support Instrument and Request for Modification of Assessment Criteria-Press Release; Staff Report; and Statement by the Executive Director for the Republic of Mozambique'. IMF Country Report 15/223. Washington, DC: International Monetary Fund. Available at: http://www.imf.org/external/pubs/ft/scr/2015/cr15223.pdf (accessed 2 June 2016).

IMF (2016a). 'Transcript of African Department Press Briefing'. 15 April. Washington, DC: International Monetary Fund. Available at: https://www.imf.org/external/np/tr/2016/tr041516a.htm (accessed 2 June 2016).

IMF (2016b). 'Republic of Mozambique Staff Report for the 2015 Article iv Consultation, Fifth Review under the Policy Support Instrument, Request for Modification of Assessment Criteria, and Request for an 18-month Arrangement under the Standby credit Facility-Press Release; Staff Report; and Statement by the Executive Director for the Republic of Mozambique'. IMF Country Report 16/9. Washington, DC: International Monetary Fund. Available at: https://www.imf.org/external/pubs/ft/scr/2016/cr1609.pdf (accessed 2 June 2016).

INE (Instituto Nacional de Estatística) (1996-2015). 'Statistical Yearbook' for years 1995-2014. Maputo: Instituto Nacional de Estatística.

INE (1999b). 'II Recenseamento Geral da População e Habitação: 1997 - Resultados definitivos'. Maputo: Instituto Nacional de Estatística.

INE (2010b). 'III Recenseamento Geral da População e Habitação: 2007 - Resultados definitivos'. Maputo: Instituto Nacional de Estatística.

INE (2015b). 'Indice de Preços no Consumidor: Moçambique, Dezembro 2014'. Maputo: Instituto Nacional de Estatística.

INE (2016a). 'Indice de Preços no Consumidor: Moçambique, Dezembro 2015'. Maputo: Instituto Nacional de Estatística.

INE (2016b). 'Indice de Preços no Consumidor: Moçambique, October 2016'. Maputo: Instituto Nacional de Estatística.

INE (2016c). 'Produto Interno Bruto: Óptica da Produção, 1991-2015'. Maputo: Instituto Nacional de Estatística. Mimeo.

INE (2016d). 'Produto Interno Bruto: Óptica da Despesa, 1991-2015’. Maputo: Instituto Nacional de Estatística. Mimeo.

INE (2016e). 'Gross Value Added by Sector: 2010-2015, Nominal Prices'. Maputo: Instituto Nacional de Estatística. Mimeo.

Jones, S. (2007). 'A economia de turismo em Moçambique: tamanho, impacto e implicações'. Documento para discussão 55p. Maputo: MPD. Available at: http://mail.mpd.gov.mz/gest/documents/55P_A_economia_de_turismo.pdf (accessed 21 February 2016).

Jones, S., H. Ibrahimo, C. Matos, H. Neves, and P. Nhampossa (2007). 'Turismo e a economia local: O caso da Praia do Bilene, Moçambique'. Documento para discussão 56. Available at: http://mail.mpd.gov.mz/gest/documents/56P_Turismo_\%20e_Economia.pdf (accessed 21 February 2016).

Jones, E.S., and F. Tarp (2012). 'Jobs and Welfare in Mozambique - Country Case Study for the 2013 World Development Report'. Available at: http:/ / siteresources.worldbank.org/EXTNWDR2013/Resources/82580241320950747192/8260293-1320956712276/8261091- 
February 2013).

Kaiser, D., and J. Rantala (2016). 'War in Peace. The Return of Civil War in Mozambique?'. Article, 27 April. Available at: http://www.sicherheitspolitik-blog.de/2016/04/27/war-in-peace-thereturn-of-civil-war-in-mozambique/ (accessed 12 December 2016).

Krause, M., and F. Kaufmann (2011). 'Industrial Policy in Mozambique'. Discussion Paper 10/2011. Bonn: German Development Institute.

MASA (Ministério da Agricultura e Segurança Alimentar) (no date). 'Anuário de Estatísticas Agrárias 2012-2014'. Maputo.

MEF (Ministério de Economia e Finanças) (2016). '4a Avaliação nacional da pobreza'. Public presentation of Household Budget Survey 2014-2015 results in Maputo, 26 October.

Menon, A. (2014). 'Selected Trade Issues for Mozambique in 2014'. Draft briefing paper, prepared for USAID - Mozambique. Nathan Associates.

MITESS (Ministério do Trabalho, Emprego e Segurança Social) (2016). 'Política Nacional de Emprego'. Maputo.

MITUR (Ministério do Turismo) (2004). 'Plano Estratégico para o Desenvolvimento do Turismo de Moçambique em 2004-2013 (PEDT I)'. Maputo. Available at: http://www.portaldogoverno.gov.mz/docs_gov/estrategia/turismo/Plano_Estrategico_pt _MITUR.pdf (accessed 21 February 2015).

MITUR (2013). 'Oportunidade e desafios do sector do turismo em Moçambique'. Discurso do Ministro. Available http:/ /www.cplp.org/Admin/Public/Download.aspx?file=Files $\% 2 F F i l e r \% 2 F t u r i s m o \% 2 F$ Conferencia_Ministros $\% 2$ FVII+Conferencia_Ministros $\% 2$ FP1\%2FInterveno-Min-TurMoambique.doc (accessed 2 February 2016).

MITUR (2015a). 'Plano Estratégico para o Desenvolvimento do Turismo de Moçambique em 2015-2024 (PEDT II), Documento em elaboração'. Maputo.

MITUR (2015b). 'VIII reunião dos ministros do turismo da CPLP em Timor-Leste'. Discurso do Ministro. Available at): http:/ / www.cplp.org/Admin/Public/Download.aspx?file=Files $\% 2 F F i l e r \% 2 F t u r i s m o \% 2 F$ Conferencia_Ministros $\% 2 \mathrm{FMo} \% \mathrm{C} 3 \%$ A7ambique_VF-Turismo-e-Globalizacaofinalissima.pdf (accessed 2 February 2016).

Mosca, J., A.Y. Dadá, and K.A. Pereira (2014). 'Influência das taxas de câmbio na agricultura'. Observador Rural (OMR): Documento de Trabalho 20, September.

MPD (Ministério da Planificação e Desenvolvimento) (2010). 'Poverty and Well-being in Mozambique: Third National Poverty Assessment'. Maputo: National Directorate of Studies and Policy Analysis, Ministry of Planning and Development.

MPD (2014). 'Estratégia Nacional de Desenvolvimento'. Maputo.

MPD and MF (Ministério da Planificação e Desenvolvimento e Ministério das Finanças) (2012). ‘Cenario Fiscal de Médio Prazo: 2013-2015’. Maputo, June.

MPF-DNE (Ministério do Plano e Finanças - Direcção Nacional de Estatísticas) (1994-1995). 'Anuário Estatístico para os anos 1993-1994'. Maputo: Direcção Nacional de Estatística.

MTC (Ministério dos Transportes e Comunicações) (2016). 'Informação estatística'. Mimeo.

OANDA (2016). 'Exchange Rate Conversion USD1 for Meticais 77.00 on 14 October 2016'. Available at: https://www.oanda.com/currency/converter/ (accessed 15 November 2016). 
Pauw, K., J. Thurlow, R. Uaiene, J. Mazunda (2012). 'Agricultural Growth and Poverty in Mozambique: Technical Analysis in Support of the Comprehensive Africa Agricultural Development Program (CAADP)'. IFPRI Working Paper 2, November.

PdM (Parlamento de Moçambique) (2007). 'Lei do Trabalho'. Lei n. 23/2007 de 1 Agosto, aprovada pela Assembleia da República, Boletim da República, I Série, n.31.

PdM (2009). 'Lei de reformulação da Pauta Aduaneira'. Lei n. 6/2009 de 10 Março, aprovada pela Assembleia da República, Boletim da República, I Série, n.9.

Portuguez, A.P., G. Seabra, G., and O.T.M.M. Queiroz (2012). 'Turismo, espaço e estratégias de desenvolvimento local'. Editora Universitária da UFPB. Available at: http://www.geociencias.ufpb.br/ paulorosa/Documentos/Divulgacao/livros/livroGEPT EEDL.pdf (accessed 22 February 2016).

Rand, J., and F. Tarp (2013). 'Inquérito às Indústrias Manufactureiras (IIM 2012): Relatório Descritivo'. Maputo: DNEAP-MPD; Copenhagen: KU.

Rand, J., A. Cruz, C. Newman, and F. Tarp (2014). 'Learning by Exporting: The Case of Mozambican Manufacturing'. WIDER Working Paper 2014/066. Helsinki: UNU-WIDER.

Sulemane, J. (2002). 'Dados basicos da Economia Moçambicana'. In A Economia Moçambicana Contemporanea: Ensaios. Maputo: Gabinete de Estudos, Ministério do Plano e Finanças.

Sutton, J. (2014). 'Mapa empresarial de Moçambique’. London: IGC.

Tarp, F. (1990). 'Prices in Mozambican Agriculture'. Journal of International Development, 2(2): 172208.

Tarp, F., C. Arndt, H.T. Jensen, S. Robinson, and R. Heltberg (2002). 'Facing the Development Challenge in Mozambique: An Economy-wide Perspective'. Research Report 126. Washington, DC: International Food Policy Research Institute.

Torp, J.E., and P. Rekve (1998). 'Privatisation in Developing Countries: Lessons to be Learnt from the Mozambican Case'. African e-Journals Project, Transformation, 36, Michigan State University. Available at: http://pdfproc.lib.msu.edu/?file=/DMC/African\%20Journals/pdfs/transformation/tran0 36/tran036005.pdf (accessed 2 June 2016).

USAID (United States Agency for International Development) (2004). 'Removing Obstacles to Economic Growth in Mozambique: A Diagnostic Trade Integration Study (DTIS)'. Vol. 2, Main Report, December.

WSJ (Wall Street Journal) (2016). 'Tuna and Gunships: How \$850 Million in Bonds Went Bad in Mozambique, 3 April, by Matt Wirz and Julie Wernau. Available at: http:/ / www.wsj.com/articles/tuna-and-gunships-how-850-million-in-bonds-went-bad-inmozambique-1459675803 (accessed 5 April 2016). 